\title{
Ecological and economical aspects of solar energy use
}

\author{
Wiktoria Sobczyk ${ }^{1 *}$, Patrycja Pelc $^{2}$, Barbara Kowal $^{3}$ Robert Ranosz ${ }^{4}$ \\ ${ }^{1}$ Faculty of Mining \& Geoengineering, AGH University of Science \& Technology, Al. Mickiewicza \\ 30, 30-059 Krakow, Poland \\ ${ }^{2}$ Regional Directorate of Environmental Protection in Warsaw, Faculty of Environmental Impact \\ Assessment, Poland \\ ${ }^{3}$ Faculty of Mining \& Geoengineering, AGH University of Science \& Technology, Al. Mickiewicza \\ 30, 30-059 Krakow, Poland \\ ${ }^{4}$ Faculty of Mining \& Geoengineering, AGH University of Science \& Technology, Al. Mickiewicza \\ 30, 30-059 Krakow, Poland
}

\begin{abstract}
The natural environment is devastated by the industry and by households, which use fuels such as coal, oil and natural gas for heating water and buildings as well as for generating electricity. One of the ways to limit the degradation of the environment and the usage of natural resources is to use unconventional and renewable resources and to implement energysaving technologies in construction, industry and households. A dynamic development of systems based on renewable energy sources such as biomass, water, wind, heat from inside the Earth and sunbeams has recently occurred in the whole world. This thesis is related to the purest and the least onerous for environment source of energy which is undoubtedly the energy that comes directly from the solar radiation. In this article the solar energy application is presented, taking into account its impact on the environment and financial costs of developing solar techniques. The installation of alternative energy sources are entitled to grants and credits, which reduces the investment costs. Ecological effects, although immeasurable, are significant and definitely testify in favor of the solar system.
\end{abstract}

\section{Introduction}

As of the beginning of the 19th century and - in some parts of the world - even until the beginning of the 20th century, almost all energy used for human consumption came from wind, water and wood, which stored the Sun's energy. At a later point in time, people started exploiting fossil energy sources from below the Earth's surface. Their use contributed to the rapid evolution of transport and building technologies. As at the end of the 20th century, people began to notice various disadvantages of fossil fuels: limited resources, unequal distribution and environmental pollution caused by their combustion.

Future developments in science taught people how to use solar energy for both heating the dwelling houses and water as well as for producing electricity. The most important parameter

\footnotetext{
* Corresponding author: sobczyk@agh.edu.pl
} 
in solar power technology is the total annual incident radiation, which reaches the ground surface at a given point (in Poland - approx. $950 \mathrm{kWh} / \mathrm{m}^{2}$ ) [1].

Solar power is used for human consumption both passively and actively. Active solar techniques related to the process of converting solar radiation energy into other types energy mainly include the photothermal conversion (conversion of solar radiation into thermal energy in solar collectors), photovoltaics (conversion of solar radiation into electricity using photovoltaic panels) and photochemistry (chemical effects of light).

\section{Sustainable energy and energy security}

Sustainable development of energy is mainly based on its durability, which should be understood as the long-term availability. Renewable sources of energy are considered sustainable; however, their application must include such factors as source access, generation capacity, demand and dispersion in a given area.

Energy security is understood as the ability to access and use inexpensive, secure and environmentally friendly energy. One of the basic obligations of a state energy policy is to ensure the adequate level of energy security. In the 1970s, the term "security" was mostly associated with the area of military security. Now, economy and industrial economics in particular are becoming increasingly important. Security is construed not only as a lack of specific threats, but also as having opportunities to develop. The energy security of a state depends on the condition of its domestic infrastructure, including the technical condition and efficiency of the facilities and systems used in transport and distribution of fuels and energy. Moreover, it depends on the size of reserves. Another functional aspect of energy supply security is the system capacity to counteract sudden disturbances. These may be breakdowns of transport systems or loss of a supply sources.

The negative impact of supply reliability of any specific energy carriers becomes particularly sharp when raw materials cannot be obtained, when their prices increase, but also when the society is reluctant to use a specific fuel. And so, energy security as defined above, is a highly complex category. Energy security indicators, as well as its measuring units and standards should be analyzed in terms of technical (probability of supply disruption indicator), economic (costs of energy acquisition and costs of losses related to the lack of energy), and environmental (emission to the atmosphere plus the resultant threats) perspectives. In each of the areas highlighted above, threats may occur randomly or through an intentional effort of a state or organization, but they can also result from changes in the economic, political or natural environment (climate changes) [2, 3].

In terms of reduction of GHGs emissions, the following goals were formulated:

- reduction of domestic GHGs emissions by $80 \%$ until 2050 when compared with emissions in 1990 (in all EU Member States);

- program of obligatory reduction of GHGs emissions in the subsequent years: $25 \%$ in 2020 , $40 \%$ in $2030,60 \%$ in $2040,80 \%$ in 2050 [4].

More widespread utilization of low-emission technologies is emphasized in particular. In terms of energy generation, using energy from renewable sources and other low-emission solutions will be promoted. Improving the efficiency of transport will be an important priority, while another important task will be reducing energy consumption in residential construction. Strong support for renewable energy sources is reflected in its enormous share in the gross final energy consumption: approx. $75 \%$ in 2050 , with a $97 \%$ share of renewable energy sources in electricity production. 


\section{Economic analysis of the use of solar power}

The cost of using solar panels is very low. It includes the cost of driving the circulating pumps and the cost of periodical replacement (at intervals of several years) of the fluid used in the thermal circuit of the system. The most beneficial is the installation of photovoltaic cells, which are also characterized by the longest service life. The most expensive are the systems using vacuum tube collectors and flat-plate collectors. On the other hand, organic solar cells entail lower operational costs. In Poland, the cost of a complete solar set for a single-family house, where 4 people live, is PLN 16,000 (EUR 3500) depending on the type of the installed collectors, their number and execution technology.

Passive solar systems can use some elements of the building (e.g. glazing) to accumulate heat. No intermediate medium is used for heat transport and transfer. Sun rays in the form of visible and infra-red waves which penetrate into the rooms, being accumulated in walls, floors and ceilings. The elements heat up and emit thermal radiation, producing the greenhouse effect. Apart from passive solar systems, installation of photovoltaic cells, solar collectors and use of other alternative sources of energy, the construction of a low-energy house, which constitutes a method for reducing the cost of using such building, seems the most beneficial from the point of view of environmental protection and potential return on investment [5].

When building a single-storey house with a converted loft of a total floor area of $115 \mathrm{~m}^{2}$ and a pitched roof, the works begin with laying the foundations [6]. The cost of foundation slab and thermal insulation is PLN $180 / \mathrm{m}^{2}$ (EUR 40/ $\mathrm{m}^{2}$ ).

Table 1. Cost of building a traditional house and low-energy house

\begin{tabular}{|l|c|c|}
\hline \multicolumn{1}{|c|}{ Operation } & $\begin{array}{c}\text { Traditional house } \\
\text { PLN/EUR }\end{array}$ & $\begin{array}{c}\text { Low-energy house } \\
\text { PLN/EUR }\end{array}$ \\
\hline $\begin{array}{l}\text { raw state (laying foundations and building } \\
\text { foundation walls, creating anti-damp insulation } \\
\text { and thermal insulation) }\end{array}$ & $15000 / 3330$ & $21000 / 4660$ \\
\hline building shell & $105000 / 23300$ & $105000 / 23300$ \\
\hline windows, window sills, entrance door & $24000 / 5300$ & $33000 / 7300$ \\
\hline total cost of installation & $57100 / 12700$ & $114300 / 25400$ \\
\hline cost of insulation & $38800 / 8600$ & $53500 / 11900$ \\
\hline cost of building & $240000 / 53300$ & $327000 / 72200$ \\
\hline
\end{tabular}

The difference between expenses incurred in case of a traditional house and low-energy house (table 1) of the same size is approx. PLN 90,000 (EUR 20,000) and may seem major. Nonetheless, any additional investments involved will be fully recouped thanks to efficient thermal and electric energy consumption. If we decide to purchase a prefabricated frame house and dispense with a couple of technical elements, such as a heat pump, we will reduce the costs of building the low-energy house, hence its price will be comparable to the price of an average brick house [7]. Exploitation of an eco-friendly building should ensure maximum use of sunshine to light rooms, low energy consumption thanks to alternative energy sources and appropriate location, recycling of the so-called greywater, and compounding into the surrounding [8]. 


\section{Ecological analysis of the use of solar power}

Ecological effect was calculated on the basis of the simulation performed in the CASAnova program [9], using the selected building permit design [10].

The following formula was used to calculate the amount of the fuel used (B):

$$
B=\frac{E}{Q u}[k g],\left[m^{3}\right]
$$

where: E - energy demand in the building, MJ

$\mathrm{Q}_{\mathrm{u}}$ - calorific value of the fuel (the amount of heat which is emitted during the complete combustion), $\mathrm{MJ} / \mathrm{kg}, \mathrm{MJ} / \mathrm{m}^{3}$.

The amount of gaseous emission of polluting substances emitted into the atmosphere as a result of energy-releasing fuel combustion (table 2) was calculated on the basis of the following formula:

$$
E=B \times w[k g]
$$

where: $\mathrm{w}$ - emission factor, $\mathrm{kg} / \mathrm{Mg}, \mathrm{kg} / \mathrm{mln}^{3}$

For dust:

$$
\mathrm{B} \text { - amount of fuel burned, } \mathrm{Mg} \text {. }
$$

$$
E=B \times w \times \frac{100-\eta}{100-k}[k g]
$$

where: B - amount of fuel burned, $\mathrm{Mg}$;

$\mathrm{w}$ - emission factor, $\mathrm{kg} / \mathrm{Mg}$;

$\eta$ - operability of the dust collecting device, $\%$;

\begin{tabular}{|c|c|c|c|c|c|c|}
\hline Fuel & $\begin{array}{c}\text { Lower } \\
\text { Heating } \\
\text { Value }\end{array}$ & $\begin{array}{c}\text { Energy } \\
\text { demand in } \\
\text { the building } \\
\text { for domestic } \\
\text { hot water }\end{array}$ & $\begin{array}{c}\text { Amount } \\
\text { of fuel }\end{array}$ & $\begin{array}{c}\text { Ash } \\
\text { content } \\
\text { A, \% }\end{array}$ & $\begin{array}{c}\text { Amount of } \\
\text { flammable } \\
\text { parts } \\
\text { in dust, \% }\end{array}$ & $\begin{array}{c}\text { Amount } \\
\text { of total } \\
\text { sulphur } \\
\mathbf{S \%}, \\
\mathrm{mg} / \mathbf{m}^{3} \\
\end{array}$ \\
\hline $\begin{array}{l}\text { Bituminous } \\
\text { coal }\end{array}$ & $\begin{array}{c}28 \\
{[\mathrm{MJ} / \mathrm{kg}]}\end{array}$ & \multirow{3}{*}{$\begin{array}{c}24334,54 \\
{[\mathrm{MJ}]}\end{array}$} & $\begin{array}{c}869.091 \\
{[\mathrm{~kg}]}\end{array}$ & 5 & \multirow{3}{*}{10} & 0.41 \\
\hline Coke & $\begin{array}{c}27 \\
{[\mathrm{MJ} / \mathrm{kg}]}\end{array}$ & & $\begin{array}{c}901.279 \\
{[\mathrm{~kg}]}\end{array}$ & 9 & & 0.6 \\
\hline Natural gas & $\begin{array}{c}39,5 \\
{\left[\mathrm{MJ} / \mathrm{m}^{3}\right]}\end{array}$ & & $\begin{array}{c}616.06 \\
{\left[\mathrm{~m}^{3}\right]}\end{array}$ & 0 & & 40 \\
\hline
\end{tabular}

$\mathrm{k}$ - amount of flammable parts in dust, $\%$.

Table 2. Data for calculating ecological effect of combustion of various fuels $[11,12$, own elaboration]

The rates of reduction of the $\mathrm{SO}_{2}, \mathrm{NO}_{\mathrm{x}}, \mathrm{CO}, \mathrm{CO}_{2}$ and dust emission in case of meeting the energy demand in the building for domestic hot water through the solar collector system are showed on the figures 1-5. 


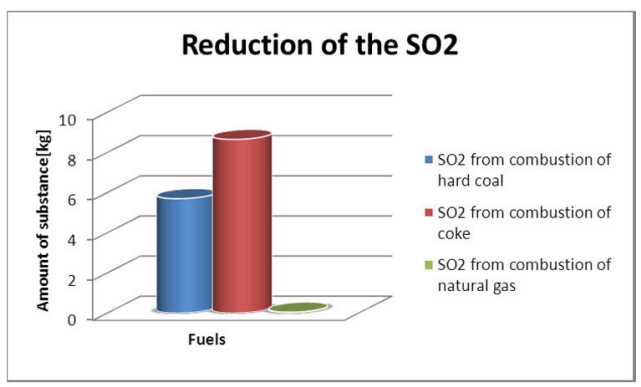

Fig. 1. The rate of reduction of the $\mathrm{SO}_{2}$ emission in case of meeting the energy demand in the building for domestic hot water through the solar collector system [own elaboration]

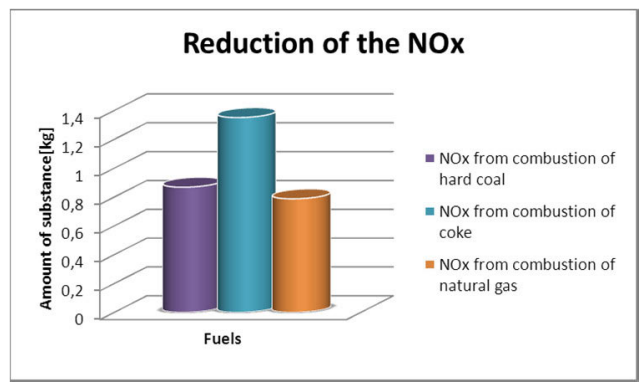

Fig. 2. The rate of reduction of the NOx emission in case of meeting the energy demand in the building for domestic hot water through the solar collector system [own elaboration]

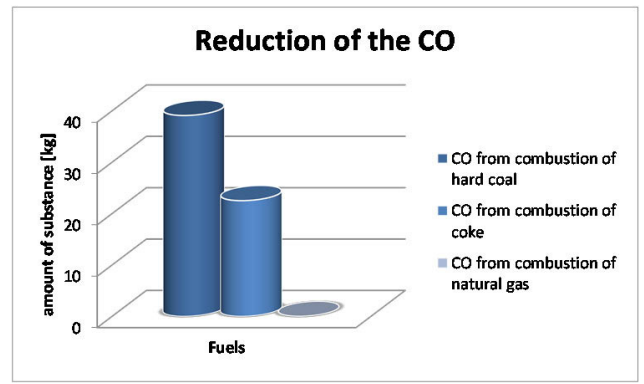

Fig. 3. The rate of reduction of the $\mathrm{CO}$ emission in case of meeting the energy demand in the building for domestic hot water through the solar collector system [own elaboration]

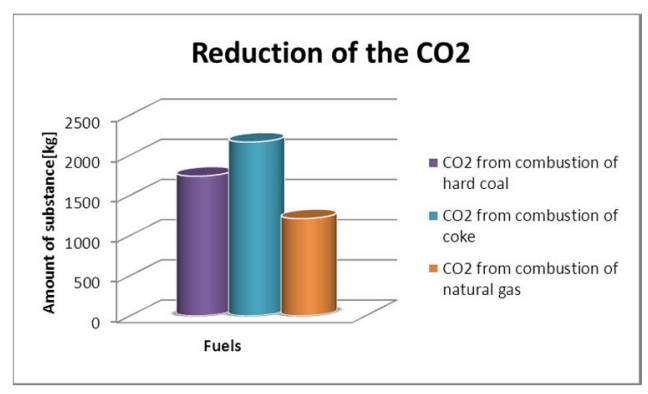

Fig. 4. The rate of reduction of the $\mathrm{CO}_{2}$ emission in case of meeting the energy demand in the building for domestic hot water through the solar collector system [own elaboration]

${ }^{*} \mathrm{CO}_{2} / 100$ - rate of reduction of the $\mathrm{CO}_{2}$ emission divided by 100 to increase readability of the graph 


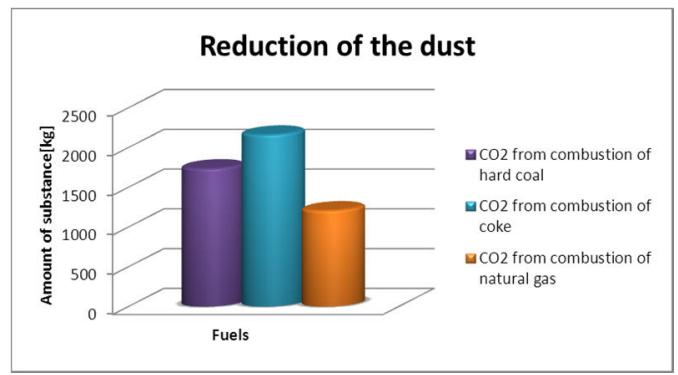

Fig. 5. The rate of reduction of the dust emission in case of meeting the energy demand in the building for domestic hot water through the solar collector system [own elaboration]

According to the calculations, it is evident that burning coke causes the greatest emission of pollutants. Combustion of coke causes greater emission only in case of CO. The smallest amount of pollution occurs due to combustion of natural gas. Changing the heat source into solar power will prevent emission of hazardous substances in quantity given in the table 3 . It must be remembered that the aforesaid pollutants are emitted by one single-family house only. On a global scale, the change of the energy source allows to avoid emission of huge amounts of pollutants.

Investment outlays on the installation of the solar power systems differ depending on the implemented technology and are much higher in case of systems used for producing electricity than in case of devices used for the production of heat energy. However, the conversion of solar radiation also has some negative environmental impact, since the production of collectors and cells consumes energy and requires natural resources, whose excavation and processing causes emission of greenhouse gases.

Table 3. The results of calculation of reduction of hazardous substances emission in case of meeting the energy demand in the building for domestic hot water through the solar collector system [own elaboration]

\begin{tabular}{|c|c|c|c|c|c|c|c|}
\hline \multirow[b]{2}{*}{ Fuel } & $\mathrm{SO}_{2}$ & NOx $_{x}$ & $\mathrm{CO}$ & $\mathrm{CO}_{2}$ & Dust & \multirow{2}{*}{$\begin{array}{c}\text { Energy } \\
\text { demand in } \\
\text { the building } \\
\text { for domestic } \\
\text { hot water }\end{array}$} & \multirow{2}{*}{$\begin{array}{l}\text { Amounts of } \\
\text { hazardous } \\
\text { substances }\end{array}$} \\
\hline & \multicolumn{5}{|c|}{$[\mathrm{kg}]$} & & \\
\hline $\begin{array}{c}\text { Bituminous } \\
\text { coal }\end{array}$ & 5.701 & 0.869 & 39.109 & 1738.182 & 7.242 & \multirow{3}{*}{$\begin{array}{c}24334.54 \\
{[\mathrm{MJ}]}\end{array}$} & $869.091[\mathrm{~kg}]$ \\
\hline Coke & 8.8652 & 1.352 & 22.532 & 2163.07 & 13.519 & & $901.279[\mathrm{~kg}]$ \\
\hline Natural gas & 0.049 & 0.789 & 0.222 & 1209.95 & 0.01 & & $616.1\left[\mathrm{~m}^{3}\right]$ \\
\hline
\end{tabular}

\section{Environmental education of the society - a chance for environmental protection}

The environmental education of society in the field of utilizing alternative solutions in building thermoregulation should therefore be the top priority for state environmental and energy policy. Raising awareness of the benefits of the implementing non-conventional solutions in residential buildings may bring about huge environmental and social gains. Thoughtless discharge of heated air into the atmosphere through building chimneys is a needless wastefulness [13-17]. 
So far 40.000 passive houses have been built in the world [18]. Inhabitants of these buildings confirm that the costs of energy have significantly dropped, while the comfort indoors remains high. Thermomodernization undertakings are a great opportunity for environmental protection, development of the labour market and cities in the future.

In terms of energy use, Poland cannot demonstrate required efficiency. This means that the depletion of natural resources, fossil fuels and environmental pollution are gradually weakening the national economy [19-20]. All the buildings in Poland completed in the past years must undergo thermomodernization and the construction of new passive buildings should commence. The cost of building a passive house is slightly higher than the cost of a traditional building (an increase by $15 \%$ of the investment outlays), however, passive constructions require no financial expenditure for the heating system. Therefore additional costs are compensated for fairly quickly. Furthermore, the construction of a passive house does not require testing new building materials as well-known materials are used, such as are also used in traditional construction. Erecting passive buildings is based on technologies which have already been tried and tested. This means that passive technologies may be used in a wide range of applications.

Educating the society about the possibilities offered by the modern construction industry is necessary for passive buildings to become more popular. Investors usually concentrate on standard solutions - cheap and easy to implement, without making the effort to find out what else is available. The designer's task is to present all solutions and to spread knowledge about innovations, so that we can enjoy living in healthy, energy-efficient, green houses.

\section{Conclusions}

Sustainable development of energy requires reduction of pressure on the environment by dispensing with large amounts of goods, whose production is related to the demand for natural resources. The supply of energy raw materials must be also secured, which is possible thanks to the reduced energy consumption and replacement of traditional energy sources by renewable sources.

To solve the problem of excessive emission of greenhouse gases caused by the combustion of fossil fuels, the return to the renewable energy sources must be implemented. The total resources of energy from renewable sources far exceed the demand for both current and future generations.

An economy must be built on the basis of sustainable development, where the correlations between economic growth, concern for the natural environment and quality of life are deliberately shaped.

Acknowledgements: The paper has been prepared within the AGH University of Science and Technology - statutory research work No 11.11.100.482.

\section{References}

1. M. Nowicki, (Nadchodzi era Słońca), Państw. Wyd. Nauk., Warszawa (2012)

2. K. Stala-Szlugaj, Solid Waste from Hard Coal Combustion in the Municipal and Housing Sector, Ann. Set The Env. Prot., 14, 909-918 (2012)

3. K. Stala-Szlugaj, PM Emission from Hard Coal Combustion in Heating Plants of Thermal Power Under 50 MW According to Obligatory Standards Emission, Ann. Set The Env. Prot., 15, 1689-1704 (2013)

4. http://ec.europa.eu/clima/citizens/eu/index_pl.htm 
5. A. Ostrowska, W. Sobczyk, M. Pawul, Evaluation of economic and ecological effects of solar energy on the example of a single-family house, Ann. Set The Env. Prot., 15 (2013)

6. Ustawa - Prawo budowlane. Dz.U. 2016, nr 0, poz. 290 Rzeczypospolitej Polskiej z dnia 9 lutego 2016 r. w sprawie ogłoszenia jednolitego tekstu ustawy - Prawo budowlane (isap.sejm.gov.pl)

7. www.kb.pl

8. S. Belniak, M. Głuszak, M. Zięba M., (Budownictwo Ekologiczne - Aspekty ekonomiczne). Wyd. Nauk. PWN, Warszawa (2013)

9. http://nesa1.uni-siegen.de/index.htm/softlab/casanova_e.htm

10. H. Koczyk, B. Antoniewicz, M. Basińska, (Ogrzewnictwo praktyczne. Projektowanie. Montaż. Certyfikacja energetyczna. Eksploatacja), Wyd. SYSTHERM D. Gazińska s.j., Poznań (2009)

11. www.kwsa.pl

12. http://egesa.pl/gaz_ziemny

13. A. Malada, W. Sobczyk, (Uprawa roślin energetycznych jako forma aktywizacji środowisk wiejskich), Zesz. Nauk. Kat. Inż. Proc. Uniwersytetu Opolskiego, II, 92-98 (2005)

14. W. Sobczyk, The energetic basket willow's harvest - in the light of investigations, Polityka Energetyczna, 10, 2, 547-556 (2007)

15. W. Sobczyk, Evaluation of harvest of energetic basket willow, TEKA Kom. Mot. i Energ. Roln. PAN, XI, 343-352 (2011)

16. B. Klojzy-Karczmarczyk, Variability of Mercury Content in Various Fractions of Soils from the Vicinity of Krakow Ring Road Section, Ann. Set The Env. Prot. 16, 1, 363 375 (2014)

17. B. Klojzy-Karczmarczyk, Analysis of Long-term Research on Mercury Content in the Soils in the Immediate Surroundings of the Southern Ring Road of Krakow, Ann. Set The Env. Prot. 15, 2, 1053-1069 (2013)

18. gazetaprawna.pl/nieruchomosci/artykuly/domy-pasywne 2014

19. B. Kowal, D. Kowal, M. Karkula, Sustainable development in the model of mining company strategy. Pol. Journ.of Env. Stud., 21, 5A, 222-226 (2012)

20. R. Ranosz, Mining and its role in the global economy. Mineral Res. Manag., 30, 1, 520 (2014). 